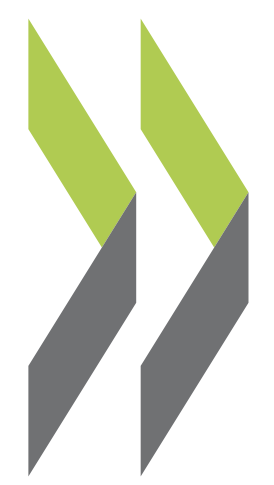

OECD Economics Department Working Papers No. 1618

Unpicking Portugal's export performance: A microdata analysis

\section{Paula Adamczyk,} Ben Westmore 


\section{ECONOMICS DEPARTMENT}

\section{UNPICKING PORTUGAL'S EXPORT PERFORMANCE: A MICRODATA ANALYSIS}

\section{ECONOMICS DEPARTMENT WORKING PAPERS No. 1618}

By Paula Adamczyk and Ben Westmore

OECD Working Papers should not be reported as representing the official views of the OECD or of its member countries. The opinions expressed and arguments employed are those of the author(s).

Authorised for publication by Isabell Koske, Deputy Director, Country Studies Branch, Economics Department.

All Economics Department Working Papers are available at www.oecd.org/eco/workingpapers.

JT03465033 
OECD Working Papers should not be reported as representing the official views of the OECD or of its member countries. The opinions expressed and arguments employed are those of the author(s).

Working Papers describe preliminary results or research in progress by the author(s) and are published to stimulate discussion on a broad range of issues on which the OECD works.

Comments on Working Papers are welcomed, and may be sent to the Economics Department, OECD, 2 rue André-Pascal, 75775 Paris Cedex 16, France, or by e-mail to eco.contact@oecd.org.

All Economics Department Working Papers are available at www.oecd.org/eco/workingpapers.

This document and any map included herein are without prejudice to the status of or sovereignty over any territory, to the delimitation of international frontiers and boundaries and to the name of any territory, city or area.

The statistical data for Israel are supplied by and under the responsibility of the relevant Israeli authorities. The use of such data by the OECD is without prejudice to the status of the Golan Heights, East Jerusalem and Israeli settlements in the West Bank under the terms of international law.

○ OECD (2020)

You can copy, download or print OECD content for your own use, and you can include excerpts from OECD publications, databases and multimedia products in your own documents, presentations, blogs, websites and teaching materials, provided that suitable acknowledgment of OECD as source and copyright owner is given. All requests for commercial use and translation rights should be submitted to rights@oecd.org 


\section{Abstract/Résumé \\ Unpicking Portugal's Export Performance: A Microdata Analysis}

Portugal has notably increased its international openness over recent decades, with exports' share of GDP rising by 20 percentage points since 1993 . This analysis couples microdata with panel regression techniques to investigate the drivers of Portuguese export growth over the 1995-2016 period. The results highlight that there was no one single factor behind the export expansion. While an improvement in price competitiveness played a significant role, the majority of the increase in exports was explained by other factors. These include increases in the quality of export products and weak domestic demand that prompted firms to increase their focus on foreign markets. The empirical results also suggest that the restoration of the health of the Portuguese financial sector and its further development is beneficial for export growth.

This Working Paper relates to the 2019 OECD Economic Survey of Portugal (www.oecd.org/economy/portugal-economic-snapshot/).

JEL classification: F10, F14, F43, F65, C32, C55.

Keywords: Portugal, export performance, international trade, microdata, competitiveness, financial development.

\section{Découper les performances à l'exportation du Portugal : une analyse à partir de microdonnées}

Le Portugal a fortement accru son ouverture internationale au cours des dernières décennies, la part des exportations dans le PIB ayant augmenté de 20 points de pourcentage depuis 1993. Cette étude associe une analyse des microdonnées aux techniques de régression par panel pour étudier les moteurs de la croissance des exportations portugaises au cours de la période. Les résultats montrent qu'il n'y avait pas un seul facteur derrière l'expansion des exportations. Si l'amélioration de la compétitivité-prix a joué un rôle important, la majeure partie de l'augmentation des exportations s'explique par d'autres facteurs. II s'agit notamment de l'augmentation de la qualité des produits d'exportation et de la faiblesse de la demande intérieure qui ont incité les entreprises à se concentrer davantage sur les marchés étrangers. Les résultats empiriques suggèrent également que le rétablissement de la santé du secteur financier portugais et son développement sont bénéfiques pour la croissance des exportations.

Le présent document de travail concerne l'Étude économique 2019 du Portugal (www.oecd.org/fr/economie/portugal-en-un-coup-d-oeil/).

Classification JEL : F10, F14, F43, F65, C32, C55.

Mots clés : Portugal, performance à l'exportation, commerce international, micro-données, compétitivité, développement financier. 


\section{Table of contents}

Unpicking Portugal's export performance: a microdata analysis 5

Introduction $\quad 5$

$\begin{array}{ll}\text { Empirical strategy } & 7\end{array}$

Data $\quad 8$

Results 10

$\begin{array}{ll}\text { Product-level results } & 10\end{array}$

Firm-level results $\quad 12$

The importance of financial sector developments for Portuguese exporters 14

$\begin{array}{ll}\text { Summary } & 16\end{array}$

References $\quad 17$

$\begin{array}{ll}\text { ANNEX } & 19\end{array}$

\section{Tables}

$\begin{array}{lr}\text { Table 1. Product-level results } & 10\end{array}$

Table 2. Product-level results with interaction terms for the 2009-2016 period 12

Table 3. Firm-level results $\quad 13$

Table 4. The impact of finance on export growth 16

\section{Figures}

Figure 1. Exports of goods and services

Figure 2. Exports have become more price competitive and specialisation has broadened 6

Figure 3. The export boom was accompanied by very weak domestic demand 7 


\title{
Unpicking Portugal's export performance: a microdata analysis
}

\author{
By Paula Adamczyk and Ben Westmore ${ }^{1}$
}

\section{Introduction}

Portugal has markedly increased its international trade intensity over the past two and a half decades. While exports accounted for $23.6 \%$ of GDP in 1993, this proportion had risen to just below $44 \%$ in 2019 . The increase in export intensity was especially pronounced from 2009 , despite weak demand conditions in most of Portugal's major trading partners. Indeed, the period was characterised by consistent gains in the penetration of Portuguese exports into foreign markets (i.e. gains in market share). Between 2009 and 2019 , the nominal and real value of exports rose by $94 \%$ and $75 \%$ respectively.

The improvement in export performance coincided with increased integration into global value chains and a larger proportion of firms beginning to export (Westmore and Adamczyk, 2019). At the sectoral level, the contribution of the tourism sector was particularly large. Nevertheless, a number of manufacturing sectors (e.g. minerals and metals, chemicals machinery, agri-food, transport material) also contributed strongly (Westmore and Adamczyk, 2019), suggesting that some factors impacting across sectors have supported the rise in aggregate exports.

\section{Figure 1. Exports of goods and services}

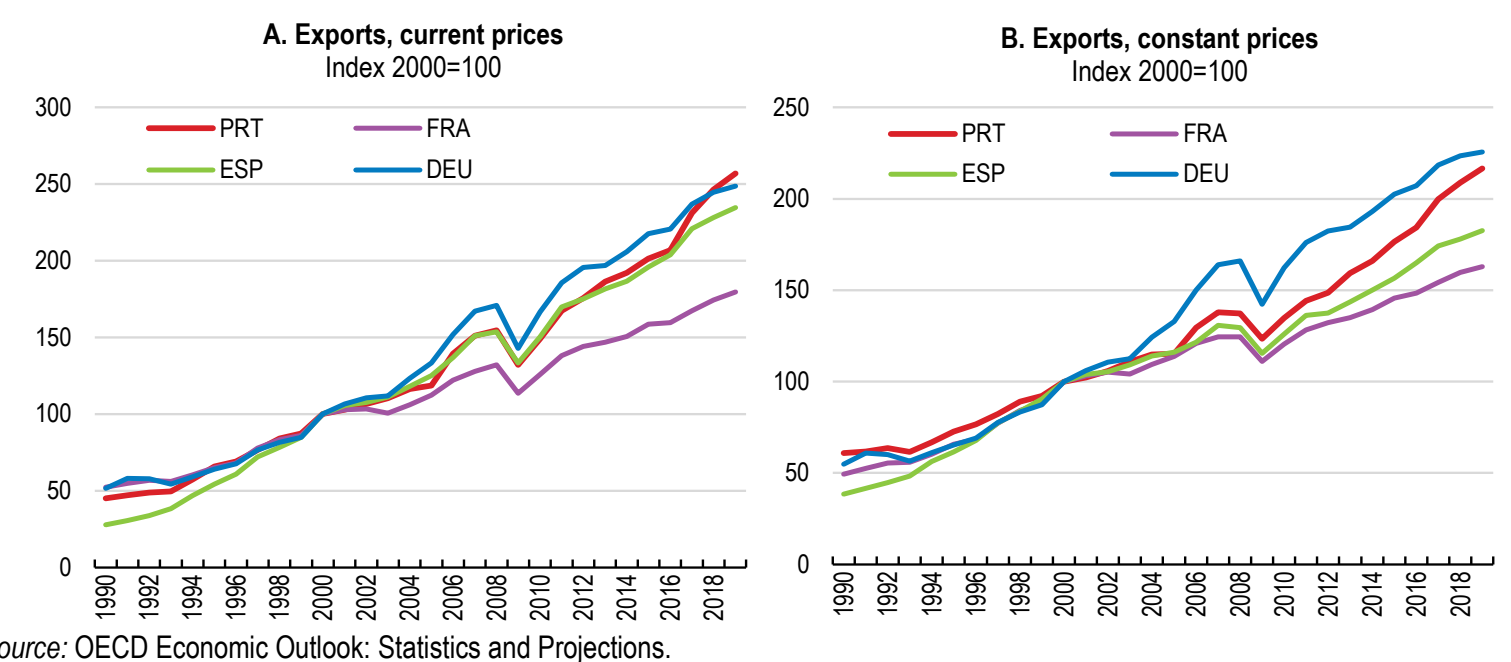

1.Paula Adamczyk (paula.adamczyk@oecd.org) and Ben Westmore (ben.westmore@oecd.org) are members of the OECD Economics Department. They would like to thank David Haugh, Sebastian Benz, Alex Jaax, Yosuke Jin, Pierre Beynet (all from the OECD) and Miguel Coelho (Portuguese Ministry of Finance) for comments on earlier drafts. The authors would also like to thank Statistics Portugal and Thomas Chalaux for providing some of the data used in the analysis, along with Sylvie Ricordeau for technical assistance. 


\section{6 | ECO/WKP(2020)26}

An improvement in price competitiveness may have been one driver of the export recovery (Felke and Eide, 2014), with Portuguese export prices relative to its competitors declining by around $6 \%$ from 2003 to 2017 (Figure 2, Panel A). Concurrently, there were larger improvements in the quality of export products in Portugal than in other European countries such as Germany and France (Westmore and Adamczyk, 2019). Manufacturing exporters have also broadened their activities, becoming specialised in a larger set of product categories (Figure 2, Panel B).

Figure 2. Exports have become more price competitive and specialisation has broadened

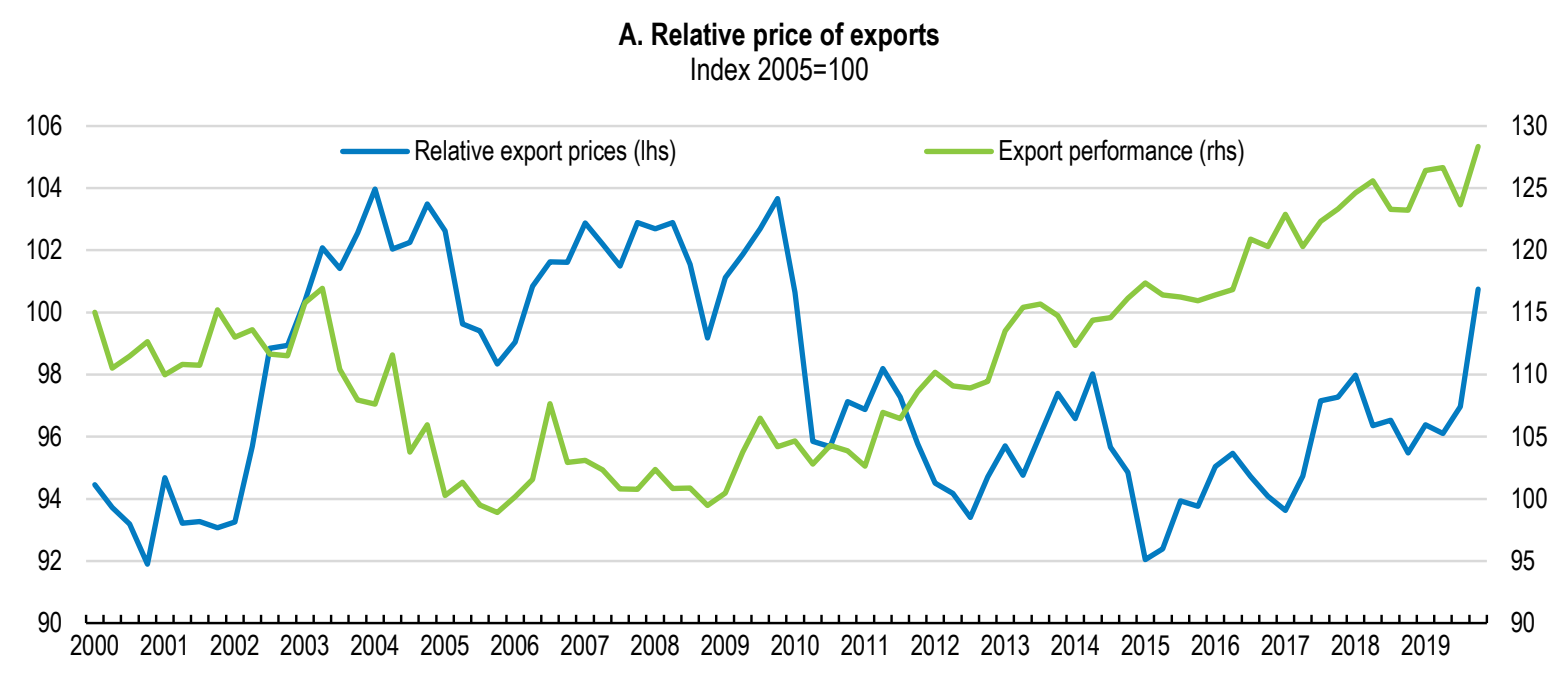

B. Change in the share of products with a revealed comparative advantage, 2000-15

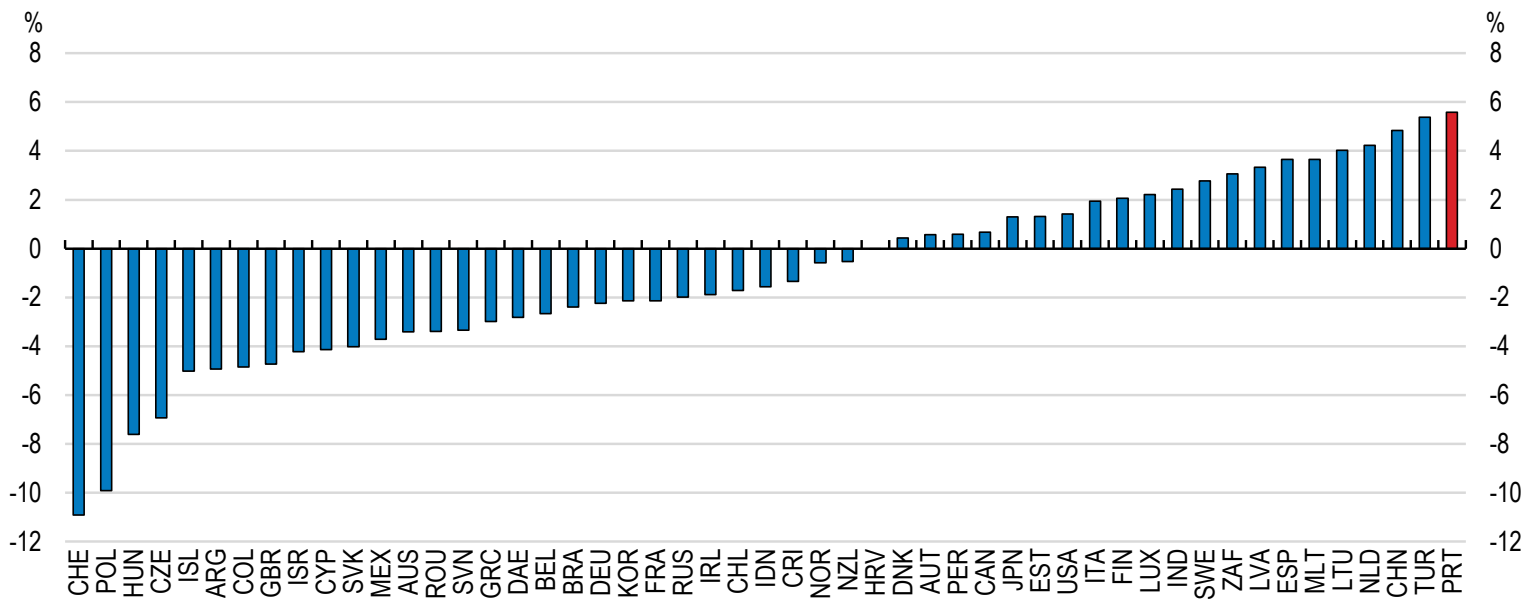

Note: Panel A shows a trade-weighted measure of Portuguese export prices relative to those of competitor economies. Further explanation of the index can be found in Morin and Schwellnus, 2014. In Panel B, the measure is taken from Araujo, Chalaux and Haugh, 2018, where the share of products is the number of products with a revealed symmetric comparative advantage on the total number of products exported by each country. A country has a revealed comparative advantage when the export share of product $p$ in their export basket is higher than the corresponding share of product $p$ in world exports.

Source: OECD Economic Outlook (database); Araujo, Chalaux and Haugh, 2018. 
One of the catalysts for more firms increasing the quality and scope of their exports was weak domestic demand. Past work has highlighted a negative relationship between the evolution of domestic demand and exporting behaviour in Portugal, controlling for other influences such as external demand and the real exchange rate (Esteves and Rua, 2015). The underlying intuition is that a decline of domestic sales increasingly motivates firms to look to external markets as a final destination for their products. At the aggregate level, there appears to have been a particularly strong negative relationship between Portuguese domestic demand and exports in the 2010-14 period (Figure 3). Similar patterns were also observed in Spain and Greece around the same time (Almunia et al., 2018). Nevertheless, changes in the intensity of international competitive pressures may have affected the extent to which firms were able to reorient themselves to the external sector (Amador and Cabral, 2008). Domestic factors that may be influenced by government policy, such as access to finance, may have also been important in influencing the extent to which firms could take advantage of export opportunities.

\section{Figure 3. The export boom was accompanied by very weak domestic demand}

Components of aggregate demand, average annual percentage change

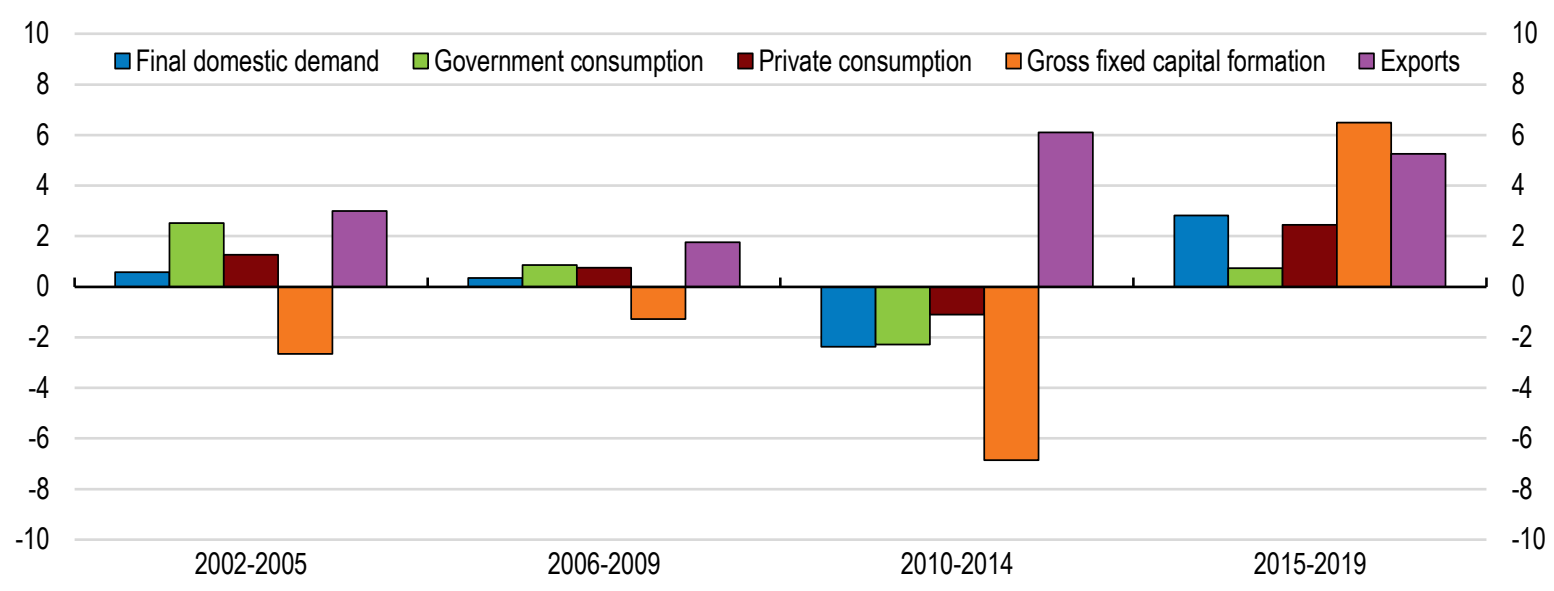

Source: OECD Economic Outlook database.

Quantifying the relative influence of these factors on Portugal's export performance is vital for policymakers wanting to better understand recent fluctuations in economic activity. The analysis here seeks to increase the precision with which their influence can be identified, through utilising data with a high level of granularity (i.e. at both the product and firm level). In what follows, Section 2 details the empirical strategy for exploring the main determinants of export growth. Section 3 discusses the data used for the analysis as well as the calculations employed to construct key variables before Section 4 outlines the key results and Section 5 concludes.

\section{Empirical strategy}

The empirical analysis is performed using data at both the product-level and firm-level. This is because product-level results may give insights that are masked at the firm-level, not least because of the availability of product-specific measures of export quality and world demand that can be used in the regressions. Similarly, the available datasets allow for some attributes of firms to be incorporated in the firm-level analysis that provide additional insights on the drivers of export performance. Re-estimating the models using two separate datasets also provides an opportunity to test the robustness of the key findings. 


\section{8 | ECONKR(2020)26}

In the product-level regressions, a general export growth equation is specified in the spirit of recent empirical work on the topic by Bugamelli et al. (2017) and Araujo, Chalaux and Haugh (2018). Specifically, the regression equation is defined as:

$$
\Delta \text { Exports }_{\mathrm{i}, \mathrm{t}}=\alpha_{0}+\alpha_{1} \Delta \text { Exports } \mathrm{t}-1_{1}+\alpha_{2} \Delta \text { WorldDemand }_{\mathrm{i}, \mathrm{t}}+\alpha_{2} \Delta \text { Quality }_{\mathrm{i}, \mathrm{t}}+\mathbf{X}^{\prime} \beta+\mathrm{Z}^{\prime} \rho+\delta_{\mathrm{t}}+\lambda_{\mathrm{i}}+\varepsilon_{\mathrm{i}, \mathrm{t}}
$$

Where $\Delta$ indicates log differences, $\Delta$ Exports is the rate of growth of the export values of product $i$ in time period $t$. Following Araujo, Chalaux and Haugh (2018), a lagged dependent variable is included to control for mean reversion in the pattern of exports. $\Delta$ WorldDemand is the growth rate of world demand and $\Delta$ Quality is the growth rate of export quality. $\boldsymbol{X}$ is a vector of country-level variables such as relative export prices and domestic demand. Both of these variables are included as lagged values as it takes time for export activity to respond to a shock in either. $\boldsymbol{Z}$ is a vector of variables reflecting the change in the share of overlap in revealed symmetric comparative advantage (defined further below) with a particular country in a given year. Product and time fixed effects are included, represented by the variables $\lambda$ and $\delta$ respectively. The latter are particularly relevant for the regressions that only include product level variables.

The firm-level regressions adopt an identical empirical approach to that outlined in equation (1), but use the rate of growth of export values for firm $i$ as the dependent variable, and with $\Delta$ WorldDemand aggregated at the country level. Specifications using the firm-level data also include information about firm characteristics in place of the measure of export product quality. There are missing observations for particular firms in some years, meaning that the regressions are run on an unbalanced panel. The inclusion of year fixed effects in the regressions mitigates the potential for bias in the estimates deriving from this characteristic of the dataset. Nevertheless, the potential for endogeneity exists, for instance in the case of the relationship between world demand and exports. As such, care should be taken in attributing strong causality to the estimated coefficients.

\section{Data}

In accordance with the analysis of Araujo, Chalaux, and Haugh (2018), product-level data at the HS-6 digit product level are used. These are obtained from the UN Comtrade Database for the years 1995-2016. This highly disaggregated dataset contains almost 50000 observations, allowing enough degrees of freedom to perform analysis on the export activity of a single country.

Empirical studies on export performance have typically used price competitiveness and foreign demand as the principal explanatory factors. In addition to these variables, proxies for other potential determinants of export activity - specifically those highlighted in Section 1 - are also incorporated in this analysis. These include export quality, domestic demand, and competitive pressures deriving from the export activity of China, the United States and Germany (the reason for choosing these countries is detailed below). In addition, the extent to which availability of finance may also have influenced export growth (discussed in Section 4.2.1). The level of aggregation of specific variables used in each of the estimation equations is outlined in the Data Annex.

Price competitiveness is measured using the relative export prices index taken from the OECD Economic Outlook database. Measures of relative unit labour costs are sometimes used to proxy international competitiveness, though past work has highlighted that these are a poor proxy in the Portuguese context (Fontoura Gouveia et al. 2018). The relative export price index measures the prices of Portuguese exports relative to its competitors and is defined as follows:

$$
R P X G S=P X G S / P X C
$$

where $P X G S$ is the export deflator and $P X C$ is competitor export prices (see Morin and Schwellnus (2014) for details). In the absence of relative export prices at the product-level, this country-level indicator is a good proxy of changes in price competitiveness, as it takes into account the trade-weighted changes in the relative exchange rate adjusted export prices of all Portugal's competitors for each specific export 
market. This measure is also chosen in preference to the export price deflated real effective exchange rates published by the European Commission, as it is based on a broader set of competitor countries and the weights are derived from a trade matrix that reflects trade in both goods and services (rather than just goods). Regardless, the results presented further below are robust to the use of different measures of relative export prices, including those that relate just to goods.

A measure of annual domestic demand is taken from the OECD National Accounts and is defined as the sum of final consumption, investment and stock building expenditures by the private and general government sectors in real terms. At the product level, an indicator of world demand is defined as world exports of a given product excluding Portuguese exports in each year, calculated using the HS-6 digit product-level data. This is consistent with the measure used in the work of Araujo, Chalaux and Haugh (2018).

Export quality is proxied by trade unit values from the CEPII-BACII database which are also available at the HS-6 digit product level for the years 2000-2016. The unit values are calculated based on the "Tariff Lines" database of the United Nations Statistical Division, and are defined as the value per ton of each product category.

In order to control for competition from other exporting countries, an indicator based on the measure of revealed symmetric comparative advantage is calculated. A similar measure, proposed by Balassa (1965), has been commonly used in the literature to measure trade specialisation. This indicator of revealed comparative advantage (RCA) is defined as follows:

$$
R C A_{c, p}=\frac{\text { Exports }_{c, p} / \Sigma_{p} \text { Exports }_{c, p}}{\text { Exports }_{\text {world }, p} / \Sigma_{p} \text { Exports }_{\text {world }, p}}
$$

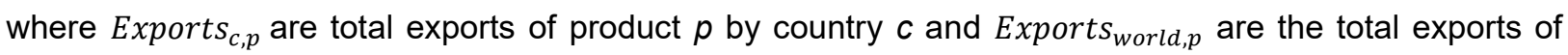
product $p$ in global trade. The problem with Balassa's RCA index is that it is asymmetric. That is, it takes values from 0 to 1 for products in which countries have a revealed comparative disadvantage and values from 1 to infinity for products in which countries have a revealed comparative advantage.

Following the approach of Araujo, Chalaux and Haugh (2018), the indicator is normalised for the analysis to take values between -1 and 1 . This revealed symmetric comparative advantage indicator (RSCA) is defined as follows:

$$
R S C A_{c, p}=\frac{R C A_{c, p}-1}{R C A_{c, p}+1}
$$

The greater the value of the RSCA indicator for a given product $p$, the greater the weight of that product in the country's export basket. When $R S C A_{c, p}$ is greater than 0 , the country is said to be specialised in that product. External competitive pressures are then accounted for in this analysis through a measure of RSCA overlap, which is the share of products in which both Portugal and any other given country are specialised in a given year. China, the United States, and Germany are chosen as the countries against which competition is assessed since they are the countries with which Portugal experienced the greatest change in the share of RSCA overlap during the 1995-2016 period.

In the second part of the paper, we investigate further the export performance of Portuguese firms using firm-level data. In order to do this, two datasets were used through an agreement for the use of microdata for scientific research purposes with Statistics Portugal. The first is the Comercio Internacional dataset that contains information on the export activity of Portuguese firms compiled from the Intra European Community Trade Statistics (Intrastat) and Extra European Trade Statistics (Extrastat). This highly disaggregated dataset contains information on firms goods exports and imports at the 8-digit product level, by year, destination, type of transport and type of exchange. Benchmarking the value of exports in the database with that in the Portuguese National Accounts suggests that the dataset covers the universe of goods exporters. For the purpose of the analysis, exports were aggregated into annual values at the firm- 
level. The dataset was then merged with some of the variables used in the product-level dataset such as world demand (aggregated to annual values), domestic demand, relative export prices and the RSCA overlap dummies. This augmented dataset was then merged with the Quadros de Pessoal Empresas dataset using firm-level identifiers, which provides information about the characteristics of individual businesses such as the value of sales, number of employees, sector of economic activity, year of establishment, equity value and the legal nature of the entity (allowing foreign-owned firms to be identified). When merging the datasets together, almost $80 \%$ of the exporting firms covered in the Comercio Internacional dataset were matched to those in the Quadros de Pessoal Empresas.

The combined dataset is available for the years 1988-2016. Nevertheless, the analysis is performed over the same period as the product-level regressions, 1995-2016. In addition to the previously mentioned control variables, two firm-specific measures are included: foreign ownership and size. Foreign ownership is a dummy that takes the value of 1 if the firm is a foreign-owned entity, while size is measured by the number of employees within the firm.

\section{Results}

\section{Product-level results}

The regression results of a series of specifications are presented in Table 1. Firstly, Column (1) highlights the effect of foreign demand and export quality on export growth. The estimates suggest that an increase in product quality and foreign demand were both accompanied by an increase in export growth at the product level.

\section{Table 1. Product-level results}

Dependent variable $=\Delta \ln ($ exports $)$

\begin{tabular}{|c|c|c|c|c|}
\hline EXPLANATORY & (1) & (2) & (3) & (4) \\
\hline VARIABLES & Model 1 & Model 2 & Model 3 & Model 4 \\
\hline \multirow[t]{2}{*}{$\Delta \ln ($ exports(-1)) } & $-0.25^{\star \star \star}$ & $-0.25^{\star \star \star}$ & $-0.25^{\star \star \star}$ & $-0.25^{\star \star \star}$ \\
\hline & $(0.00)$ & $(0.00)$ & $(0.00)$ & $(0.00)$ \\
\hline \multirow[t]{2}{*}{$\Delta \ln ($ world demand $)$} & $0.23^{\star * *}$ & $0.23^{\star * *}$ & $0.23^{\star * *}$ & $0.23^{* * *}$ \\
\hline & $(0.03)$ & $(0.03)$ & $(0.03)$ & $(0.03)$ \\
\hline \multirow[t]{2}{*}{$\Delta \ln$ (export quality) } & $0.05^{* * *}$ & $0.05^{* * *}$ & $0.05^{* * *}$ & $0.05^{* * *}$ \\
\hline & $(0.01)$ & $(0.01)$ & $(0.01)$ & $(0.01)$ \\
\hline \multirow[t]{2}{*}{$\Delta \ln ($ relative export prices $(-1))$} & & $-3.06^{* * *}$ & & $-5.09^{\star \star *}$ \\
\hline & & $(0.68)$ & & $(0.39)$ \\
\hline \multirow[t]{2}{*}{$\Delta \ln ($ domestic demand $(-1))$} & & & $-8.04^{* * *}$ & $-6.60^{* * *}$ \\
\hline & & & $(1.79)$ & $(0.49)$ \\
\hline \multirow[t]{2}{*}{$\Delta$ (RSCA overlap with China) } & & & & $-0.14^{* * *}$ \\
\hline & & & & $(0.01)$ \\
\hline \multirow[t]{2}{*}{$\Delta($ RSCA overlap with USA $)$} & & & & $-0.19^{\star * *}$ \\
\hline & & & & $(0.01)$ \\
\hline \multirow[t]{2}{*}{$\Delta$ (RSCA overlap with Germany) } & & & & $-0.20^{* * *}$ \\
\hline & & & & $(0.02)$ \\
\hline \multirow[t]{2}{*}{ Constant } & $-0.07^{\star \star *}$ & $-0.17^{\star \star \star}$ & $0.09^{*}$ & 0.01 \\
\hline & $(0.02)$ & $(0.02)$ & $(0.05)$ & $(0.01)$ \\
\hline Observations & 48,305 & 48,305 & 48,305 & 48,305 \\
\hline
\end{tabular}

Note: Robust standard errors that are clustered at the year-level are in parentheses with ${ }^{* * *} p<0.01,{ }^{* *} p<0.05,{ }^{*} p<0.1$. "In" refers to the natural $\log$ and "(-1)" refers to the lagged value of the variable. Product and time fixed effects are included in each of the regressions. 
The results of a specification that includes a measure of price competitiveness are presented in Column (2). The estimated coefficient suggests that a decline in the price of Portuguese exports relative to competitors has been associated with a rise in exports. Furthermore, the estimates in Column (3) indicate that domestic demand contractions are associated with stronger export activity, reflecting the posited relationship and providing support to the earlier results of Esteves and Rua (2015) for Portugal. While the theoretical relationship between domestic demand and exports is ambiguous (Belke, Oeking and Setzer, 2014), this empirical finding also echoes those of earlier studies for other countries which found a negative relationship. For example, Almunia et al. (2018) used Spanish firm-level data to highlight the "vent-forsurplus" mechanism that incentivised firms to increase sales to foreign markets during domestic demand slumps. Belke, Oeking and Setzer (2013) also found a substitutive relationship between domestic demand and export activity in Spain, Portugal and Italy. They also found a negative relationship in Ireland and Greece, but only in periods of a downturn in the business cycle.

Variables capturing the extent of external competitive pressure from exporters from China, the United States and Germany are included in the specification detailed in Column (4), along with the measures of price competitiveness and domestic demand already discussed. The results suggest a negative relationship between external competition deriving from these sources and Portuguese export growth. Examining the underlying data, the share of specialisation overlap between Portugal and China decreased over the 1995-2016 period, but this easing in competitive pressures on Portuguese exporters was offset by increased overlap with the United States and Germany.

Given Portugal's strong export performance has been particularly notable since 2009, interaction variables were included to capture any differential estimated effects over in the 2009-2016 sub-period. Specifically, a time dummy for the 2009-16 period is interacted with the measures of export quality, relative export prices and domestic demand.

All of the interaction terms are statistically significant and reveal interesting characteristics of Portuguese export performance in the post-2009 period. The results in the first column of Table 2 suggest that quality was less of a factor behind export performance during this period. In contrast, the results of the specifications in columns (2) and (3) suggest that a given decline in domestic demand and relative export prices had a particularly large impact on export growth in the 2009-16 period. The positive statistically significant coefficient on the measure of export prices in Column (2), which is a measure of the impact of export prices in the 1995-2008 period, is puzzling. It may be that some of the impact of the improvement in the quality of export products is not reflected in the measure of unit values that is used as a proxy but is captured only through rising export prices. 
Table 2. Product-level results with interaction terms for the 2009-2016 period

Dependent variable $=\Delta \ln ($ exports $)$

\begin{tabular}{|c|c|c|c|}
\hline EXPLANATORY & (1) & $(2)$ & (3) \\
\hline VARIABLES & Model 1 & Model 2 & Model 3 \\
\hline \multirow[t]{2}{*}{$\Delta \ln ($ exports $(-1))$} & $-0.25^{\star \star \star}$ & $-0.25^{\star \star *}$ & $-0.25^{\star \star \star}$ \\
\hline & $(0.00)$ & $(0.00)$ & $(0.00)$ \\
\hline \multirow[t]{2}{*}{$\Delta \ln ($ world demand $)$} & $0.23^{* * *}$ & $0.23^{* * *}$ & $0.23^{* * *}$ \\
\hline & $(0.03)$ & $(0.03)$ & $(0.03)$ \\
\hline \multirow[t]{2}{*}{$\Delta \ln$ (export quality) } & $0.07^{* * *}$ & $0.05^{* * *}$ & $0.05^{* * *}$ \\
\hline & $(0.01)$ & $(0.01)$ & $(0.01)$ \\
\hline \multirow[t]{2}{*}{$\Delta \ln \left(\right.$ export quality) ${ }^{*}$ dummy for $2009-2016$} & $-0.04^{* * *}$ & & \\
\hline & $(0.01)$ & & \\
\hline \multirow[t]{2}{*}{$\Delta \ln ($ relative export prices $(-1))$} & & $18.81^{* * *}$ & \\
\hline & & $(1.48)$ & \\
\hline \multirow[t]{2}{*}{$\Delta \ln (\text { relative export prices }(-1))^{*}$ dummy for $2009-2016$} & & $-21.86^{* * *}$ & \\
\hline & & $(1.86)$ & \\
\hline \multirow[t]{2}{*}{$\Delta \ln ($ domestic demand $(-1))$} & & & 1.54 \\
\hline & & & $(1.36)$ \\
\hline \multirow[t]{2}{*}{$\Delta \ln (\text { domestic demand }(-1))^{*}$ dummy for 2009-2016 } & & & $-9.59^{\star * *}$ \\
\hline & & & $(0.82)$ \\
\hline \multirow[t]{2}{*}{ Constant } & $-0.07^{* * *}$ & $-0.17^{\star * *}$ & $0.09^{*}$ \\
\hline & $(0.02)$ & $(0.02)$ & $(0.05)$ \\
\hline Observations & 48,305 & 48,305 & 48,305 \\
\hline
\end{tabular}

Note: Robust standard errors that are clustered at the year-level are in parentheses with ${ }^{* * *} p<0.01,{ }^{* *} p<0.05,{ }^{*} p<0.1$. "In" refers to the natural $\log$ and "(-1)" refers to the lagged value of the variable. Product and time fixed effects are included in each of the regressions.

\section{Firm-level results}

As outlined earlier, the same empirical specification was run on the firm-level dataset to complement the product-level results. Given that there are a number of Portuguese exporting firms in most product categories, the dataset results in a much greater number of observations (over 150000 ) than for the product-level regressions.

The estimated coefficients using the firm-level data are well-aligned with those based on product-level exports. In the first column of Table 3, the coefficients of the explanatory variables related to relative export prices, foreign demand, domestic demand and competition from China, USA, and Germany have the same sign, a similar magnitude and are all statistically significant.

The importance of price compared with non-price factors in explaining Portugal's recent export growth can be further explored through back-of-the-envelope calculations. A $6 \%$ depreciation in relative export prices - equivalent to the decline observed in the 2008-16 period - would explain an increase in exports of around 10-30 percentage points based on the range of coefficients presented in Tables 1 and 3 . As exports rose by over $70 \%$ through the period, the coefficients suggest that the majority of this increase in export values was due to non-price factors. Furthermore, foreign demand (as it is measured here) was almost flat from 2009 to 2016, suggesting that external conditions had a negligible impact on export sales. 


\section{Table 3. Firm-level results}

Dependent variable $=\Delta \ln ($ exports $)$

\begin{tabular}{|c|c|c|c|c|}
\hline EXPLANATORY & (1) & (2) & (3) & (4) \\
\hline VARIABLES & Model 1 & Model 2 & Model 3 & Model 4 \\
\hline \multirow[t]{2}{*}{$\Delta \ln ($ exports(-1)) } & $-0.32^{* \star *}$ & $-0.32^{\star \star *}$ & $-0.32^{* \star *}$ & $-0.32^{\star \star \star}$ \\
\hline & $(0.00)$ & $(0.00)$ & $(0.00)$ & $(0.00)$ \\
\hline \multirow[t]{2}{*}{$\Delta \ln ($ world demand) } & $0.59^{* * *}$ & $0.59^{* * *}$ & $1.40^{* * *}$ & $1.40^{* * *}$ \\
\hline & $(0.16)$ & $(0.16)$ & $(0.17)$ & $(0.17)$ \\
\hline \multirow[t]{2}{*}{$\Delta \ln ($ relative export prices $(-1))$} & $-4.21^{* \star \star}$ & $-4.20^{* \star *}$ & $-1.62^{* * *}$ & $-1.61^{* \star *}$ \\
\hline & $(0.49)$ & $(0.49)$ & $(0.52)$ & $(0.52)$ \\
\hline \multirow[t]{2}{*}{$\Delta \ln ($ domestic demand $(-1))$} & $-8.41^{\star \star \star}$ & $-8.40^{* \star *}$ & $-5.76^{\star \star \star}$ & $-5.75^{\star \star \star}$ \\
\hline & $(0.56)$ & $(0.56)$ & $(0.59)$ & $(0.59)$ \\
\hline \multirow[t]{2}{*}{$\Delta$ (RSCA overlap with China) } & $-0.23^{\star \star *}$ & $-0.23^{\star \star *}$ & $-0.14^{* * *}$ & $-0.14^{* \star *}$ \\
\hline & $(0.01)$ & $(0.01)$ & $(0.01)$ & $(0.01)$ \\
\hline \multirow[t]{2}{*}{$\Delta$ (RSCA overlap with USA) } & $-0.24^{\star * \star}$ & $-0.24^{\star \star *}$ & $-0.15^{\star * \star}$ & $-0.15^{\star \star \star}$ \\
\hline & $(0.02)$ & $(0.02)$ & $(0.02)$ & $(0.02)$ \\
\hline \multirow[t]{2}{*}{$\Delta$ (RSCA overlap with Germany) } & $-0.23^{\star \star *}$ & $-0.23^{\star \star *}$ & $-0.12^{* \star *}$ & $-0.12^{\star \star \star}$ \\
\hline & $(0.02)$ & $(0.02)$ & $(0.02)$ & $(0.02)$ \\
\hline \multirow[t]{2}{*}{ Foreign ownership dummy } & & $0.37^{\star * *}$ & & $0.30^{* *}$ \\
\hline & & $(0.12)$ & & $(0.15)$ \\
\hline \multirow[t]{2}{*}{$\Delta \ln$ (number of employees) } & & & $0.35^{\star \star \star}$ & $0.35^{\star * *}$ \\
\hline & & & $(0.01)$ & $(0.01)$ \\
\hline \multirow[t]{2}{*}{ Constant } & $-0.16^{\star * *}$ & $-0.16^{\star * *}$ & $-0.07^{* * *}$ & $-0.07^{* * *}$ \\
\hline & $(0.01)$ & $(0.01)$ & $(0.01)$ & $(0.01)$ \\
\hline Observations & 194,558 & 194,558 & 161,154 & 161,154 \\
\hline
\end{tabular}

Note: Robust standard errors are in parentheses with ${ }^{* *} p<0.01,{ }^{* *} p<0.05,{ }^{*} p<0.1$. "In" refers to the natural log and "(-1)" refers to the lagged value of the variable. Firm and time fixed effects are included in each of the regressions.

Additional information about the characteristics of exporting businesses that is available from the firm-level dataset is also used to provide insights, specifically about the impact of the characteristics of firm ownership and firm size on export growth. In Column (2), an ownership dummy that is equal to 1 if the firm is foreignowned or 0 otherwise is included. The results suggest that foreign-owned firms were associated with higher export growth. This accords with the fact that such firms in the OECD are more export-intensive than domestically-owned enterprises, which also tends to be true in non-OECD countries (Boddin, Raff and Trofimenko, 2017). Indeed, examining the underlying data highlights that foreign-owned firms have labour productivity that is three times higher than Portuguese-owned firms, on average.

In addition, the results in columns (3) and (4) indicate that expanding firms, proxied by the log difference in the number of employees, have been associated with stronger export growth. In a market where resources are allocated efficiently, those firms that are expanding the fastest should be those with higher productivity. To the extent that this translates to improved competitiveness at the firm level, the relationship between firm expansion and export growth is unsurprising. It should be noted that incomplete data coverage for the variable related to employee numbers results in the loss of over 30,000 observations for this specification, and could be the reason for some variation in the coefficients of some other variables compared to the results presented in Columns (1) and (2). Therefore, in Column (4) both firm-specific variables are included together in the regression. The results all retain statistical significance and a consistent sign with the other specifications. 


\section{The importance of financial sector developments for Portuguese exporters}

Across countries, difficulties in gaining access to finance can be an obstacle for the growth of exporters. This may be especially the case for young firms in a bank-based financial system, such as that in Portugal, that have a limited track record and minimal collateral. For such firms, the high fixed costs of establishing a distribution network, international marketing and potentially adjusting products for overseas regulatory standards, often requires external funding.

The financial crisis exacerbated financing constraints (Lee, Sameen and Cowling, 2015), particularly in countries such as Portugal with banking systems that were hard hit. In a survey by the Bank of Portugal, Portuguese firms reported increased difficulties in accessing credit as one of the most severe aspects of the economic shock in the $2010-13$ period. Through that time, around $30 \%$ of firms reported a moderate or strong increase in credit constraints (Martins, 2016).

In the past few years, some measures have suggested a notable improvement in access to finance for Portuguese enterprises. Between April 2014 and March 2018, the proportion of SMEs citing access to finance as their most important problem halved to be less than 10\% (European Central Bank, 2018). In accordance, borrowing costs declined along with the spread between the interest rate charged to smaller and larger firms (OECD, 2018).

Against this background, an empirical relationship between financial sector developments and export growth is investigated. There are multiple channels through which financial sector developments may impact exporters. The availability of credit and the extent to which investors provide equity to a business venture could be two drivers of external sales. Indeed, domestic private credit to GDP (from the International Monetary Fund) and the recovery rate for investors (cents in the dollar, taken from the World Bank) have exhibited some variability over recent decades. Due to data constraints on these dimensions at the firm or industry-level for Portugal, we use well-established empirical techniques to craft an identification strategy for evaluating their influence on export growth.

The methodology employed is based on the work of Rajan and Zingales (1998), which illustrated that variation across industries can be applied to analyse the effects of factors that vary across other dimensions, such as time. ${ }^{2}$ When estimating regression equations in the single country case of Portugal, the country-level financial variables of interest display no variation across firms through time. The advantage of the difference-in-difference approach of Rajan and Zingales is that it adds variation across another dimension, industries, to facilitate identification. The basic idea is that there is heterogeneity across industries in the extent of exposure to changes in conditions, whether they be induced by policy adjustments or other external factors. For example, the effect of improved access to credit is likely to be felt more strongly in industries that, in the absence of distortions, are more dependent on external financing. Similarly, changes in bankruptcy regimes that reduce the recovery rate of investors in the case of a firm exit may be most acutely felt in entrepreneurial industries that have higher firm turnover.

The estimation coefficient is identified through an interaction of the variable of interest (i.e. credit availability, investor recovery rate) with the sector-specific exposure variable. Specifically, the estimation equation can be written as:

$$
\Delta \text { Exports }_{\mathrm{i}, \mathrm{t}}=\mathrm{\alpha}_{0}+\mathrm{\alpha}_{1} \Delta V \mathrm{It}_{\mathrm{t}}^{*} \text { Exposure }_{\mathrm{ind}}+\delta_{\mathrm{t}}+\lambda_{\text {ind }}+\varepsilon_{\mathrm{i}, \mathrm{t}}
$$

Where $\Delta$ indicates log differences, $\Delta$ Exports is the rate of growth of the export values of firm $i$ in time period $t . \Delta V I$ is the growth rate in the variable of interest (e.g. financial development, recovery rate), Exposure is the time invariant exposure variable that differs across industries. If such differences are intrinsic to the sector (which the identification strategy relies upon), these should be apparent in all industrialised

2. This empirical strategy is applied in much of the recent literature investigating the economic impact of government policies. For other examples, see Adalet McGowan, Andrews and Millot (2018) and Andrews, Nicoletti and Timiliotis (2018). 
economies. Going a step further, an economy with fewer distortions should observe these differences most profoundly. Constructing this measure of exposure from Portuguese data is not desirable, as it could result in endogeneity of the regressors if the observed indicator of exposure is itself affected by changes in the variables of interest. For this reason, industry-level exposure indexes are computed from data for the United States. The reason for using the United States over any other particular country is the existence of reliable data and its status as a low regulation (i.e. low distortion) economy.

In estimating an equation with an interaction coefficient, such as equation (4), the two constituent terms of the interaction should be included in order for the regression to be unbiased. To allow for this, both year $\left(\delta_{t}\right)$ and industry $\left(\lambda_{\text {ind }}\right)$ fixed effects are incorporated in the estimation. ${ }^{3}$ It should be noted that the identification is based on the interaction coefficient, with the estimated statistical significance reflecting a marginal effect in addition to the sample average of the component terms. As the impact of both the component terms and other influences is absorbed in the coefficients of the fixed effects, it is difficult to provide a quantitative interpretation of the overall effect. Since the data on recovery rate from the World Bank is only available since 2004, we restrict the analysis to the years 2004-2016 in the two specifications.

The results suggest that both of the channels investigated have an influence on export activity in Portugal. Much of the existing literature has used the ratio of domestic private sector credit to GDP as an indicator of financial development. The coefficient on the Credit*external finance variable in Column 1 of Table 4 highlights that increases in financial development over time have had a larger impact on the exports of Portuguese firms in those sectors with high dependence on external finance. Consistent with past work in the field (Bravo-Biosca, Criscuolo and Menon, 2016), external financial dependence (i.e. the exposure variable) is measured by the inverse Leontief's coefficient on the input from finance and insurance from input-output tables for each sector. While a significant increase in credit could be associated with a buildup in financial imbalances, this result suggests that a well-developed financial system is important for exporters to be able to meet the sometimes substantial costs involved with international trade. These results are also consistent with recent analysis using matched bank-firm data from Italy (Bripi, Loschiavo and Ravelli, 2017) which suggested that credit supply shocks during the sovereign debt crisis had a significant negative impact on the exports of services.

The regression analysis also provides evidence that an increase in the ability for secured creditors to recover funds is positively associated with firm exports. While insolvency laws that are particularly punishing for entrepreneurs may disincentivise firm entry (Mcgowan and Andrews, 2016), weak creditor rights may reduce the willingness of investors to fund new business ventures or capital purchases. This is likely to be particularly the case in sectors where there is a high level of entrepreneurialism and business failure. As a result, the variable of interest in model 2 is the interaction between firm recovery rate (cents in the dollar) taken from the World Bank and a measure of firm turnover at the sectoral level taken from Bartelsman, Haltiwanger and Scarpetta (2009). The finding in Column (2) that greater recovery rates for creditors is associated with stronger export growth in entrepreneurial sectors is consistent with some past empirical work. For instance, Berkowitz and White (2002) found that higher personal bankruptcy exemptions cause increased credit rationing and higher interest rates in the US.

3. To further control for any omitted variables, firm fixed effects are also included in the regressions. Nevertheless, the results reported in Table 4 are robust to the approach taken by other studies (Arnold and Barbosa, 2015) of only including industry and year fixed effects. 


\section{Table 4. The impact of finance on export growth}

Dependent variable $=\Delta \ln ($ exports), $2004-16$

\begin{tabular}{lcc}
\hline & $(\mathbf{1})$ & $(\mathbf{2})$ \\
& Model 1 & Model 2 \\
\hline Credit*external finance & $0.33^{\star \star *}$ & \\
& $(0.09)$ & \\
Recovery*turnover & & $0.05^{\star}$ \\
Constant & & $(0.03)$ \\
& $0.27^{\star * *}$ & $0.25^{\star *}$ \\
Observations & $(0.06)$ & $(0.07)$ \\
\hline
\end{tabular}

Note: Robust standard errors are in parentheses with ${ }^{* * *} p<0.01,{ }^{* *} p<0.05,{ }^{*} p<0.1$. "Credit ${ }^{*}$ external finance" is calculated by multiplying log differences in domestic private sector credit to GDP by external finance dependence (as defined in the text). "Recovery*turnover" is calculated by multiplying the log difference of recovery rate (cents in the dollar) by firm turnover at the sectoral level (as defined in the text). Both the regressions presented in Table 4 include industry, year and firm fixed effects. The results are robust to only including industry and year fixed effects.

\section{Summary}

Portugal's very strong recent export growth has been attributed to a wide variety of factors. Indeed, the regression analysis presented here suggests that there was no one single factor that can be identified as the overriding reason for Portugal strongly increasing its exports. While an improvement in price competitiveness played a role, the majority of the increase in exports appears to have been explained by other factors. These include increases in the quality of export products and a slump in domestic demand that prompted firms to increase their focus on foreign markets. It appears that changes in international competitive pressures deriving from exporters in China, the United States and Germany were important for Portuguese exports, but taken together, only had a modest impact.

The empirical results also suggest that the restoration of health of the Portuguese financial sector and its further development is beneficial for export growth. In addition, while punishing bankruptcy regimes can disincentivise the entrepreneurs that are important to innovation in the export sector, insolvency settings that significantly reduce the recovery rate of creditors may lower the willingness of investors to fund such ventures. 


\section{References}

Adalet McGowan, M., D. Andrews and V. Millot (2018), "The walking dead? Zombie firms and productivity performance in OECD countries", Economic Policy, Vol. 33/96, pp. 685-736, http://dx.doi.org/10.1093/epolic/eiy012.

Almunia et al. (2018), Venting out: Exports during a domestic slump, Banco de España.

Amador, J. and S. Cabral (2008), "The Portuguese export performance in perspective: a constant market share analysis", Banco de Portugal Economic Bulletin, Vol. Autumn.

Andrews, D., G. Nicoletti and C. Timiliotis (2018), "Digital technology diffusion: A matter of capabilities, incentives or both?", OECD Economics Department Working Papers, No. 1476, OECD Publishing, Paris, https://dx.doi.org/10.1787/7c542c16-en.

Araujo, S., T. Chalaux and D. Haugh (2018), "Who's in your export market?: The changing pattern of competition in world trade", OECD Economics Department Working Papers, No. 1526, OECD Publishing, Paris, https://dx.doi.org/10.1787/d777efc3-en.

Arnold, J. and N. Barbosa (2015), "Structural policies and productivity: Evidence from Portuguese firms", OECD Economics Department Working Papers, No. 1259, OECD Publishing, Paris, https://dx.doi.org/10.1787/5jirw21mfp4kd-en.

Balassa, B. (1965), "Trade liberalisation and "revealed" comparative advantage", The Manchester School, Vol. 33/2, pp. 99-123, http://dx.doi.org/10.1111/j.1467-9957.1965.tb00050.x.

Bartelsman, E., J. Haltiwanger and S. Scarpetta (2009), "Measuring and analyzing cross-country differences in firm dynamics", in Dunne, T., J. Jensen and M. Roberts (eds.), Producer dynamics : new evidence from micro data, University of Chicago Press.

Belke, A., A. Oeking and R. Setzer (2014), "Domestic demand pressure and export dynamics-An empirical threshold model analysis for six euro area countries", EcoMod2014, No. 6780, EcoMod.

Belke, A., A. Oeking and R. Setzer (2013), "Exports and capacity constraints: a smooth transition regression model for six euro area countries", ROME Discussion Paper Series, No. 13-13, Research On Money in the Economy, Dusseldorf, http://www.rome-net.org/publications/.

Berkowitz, J. and M. White (2002), "Bankruptcy and Small Firms' Access to Credit”, NBER Working Papers, No. 9010, National Bureau of Economic Research, http://dx.doi.org/10.2139/ssrn.233248.

Boddin, D., H. Raff and N. Trofimenko (2017), "Foreign ownership and the export and import propensities of developing-country firms", World Economy, Vol. 40/12, http://dx.doi.org/10.1111/twec.12547.

Bravo-Biosca, A., C. Criscuolo and C. Menon (2016), "What drives the dynamics of business growth?", Economic Policy, Vol. 31/88, pp. 703-742, http://dx.doi.org/10.1093/epolic/eiw013.

Bripi, F., D. Loschiavo and D. Ravelli (2017), "Services trade and credit frictions: evidence from matched bank=firm data", Banco d'Italia.

Bugamelli, M. et al. (2017), "Back on track? A macro-micro narrative of Italian exports", Occasional Papers, No. 399, Banca d'Italia.

Esteves, P. and A. Rua (2015), "Is there a role for domestic demand pressure on export performance?", Empirical Economics, http://dx.doi.org/10.1007/s00181-014-0908-5. 
European Central Bank (2018), Survey on the access to finance of enterprises in the euro area October 2017 to March 2018, European Central Bank, June 2018.

Felke, R. and S. Eide (2014), "Export-driven adjustment in portugal", Intereconomics, Vol. 49/3, http://dx.doi.org/10.1007/s10272-014-0497-8.

Fontoura Gouveia, A. et al. (2018), "The Portuguese economy: Short essays on structural changes Title: The Portuguese economy: Short essays on structural changes", pp. 1-1, http://www.gpeari.gov.pt.

Lee, N., H. Sameen and M. Cowling (2015), "Access to finance for innovative SMEs since the financial crisis", Research Policy, Vol. 44, pp. 370-380, http://dx.doi.org/10.1016/j.respol.2014.09.008.

Martins, F. (2016), "How the Portuguese firms adjusted to the economic and financial crisis: main shocks and channels of adjustment", Economic Bulletin and Financial Stability Report Articles and Banco de Portugal Economic Studies.

Mcgowan, M. and D. Andrews (2016), "Insolvency regimes and productivity growth: a framework for analysis", OECD Economics Department Working Papers, No. 1309, OECD Publishing, Paris, http://www.oecd.org/eco/workingpapers.

Morin, M. and C. Schwellnus (2014), "An Update of the OECD International Trade Equations", OECD Economics Department Working Papers, No. 1129, OECD Publishing, Paris, http://dx.doi.org/10.1787/5jz2bxbkrxmv-en.

OECD (2018), Financing SMEs and Entrepreneurs, OECD Publishing, Paris.

OECD (2017), OECD Economic Surveys: Portugal 2017, OECD Publishing, Paris.

Rajan, R. and L. Zingales (1998), "Financial dependence and growth", The American Economic Review, Vol. 88/3, http://dx.doi.org/10.1057/978-1-349-95189-5 340.

Westmore, B. and P. Adamczyk (2019), "Public policy reforms to further improve Portuguese export performance", OECD Economics Department Working Papers, No. 1556, OECD Publishing, Paris. 


\section{ANNEX}

Table A1. Description of regression variables

\begin{tabular}{lcc}
\hline & Product-level exports & Firm-level exports \\
\hline World demand & product-level & country-level \\
Quality & product-level & - \\
Relative export prices & country-level & country-level \\
Domestic demand & country-level & country-level \\
RSCA overlaps & country-level & country-level \\
Foreign ownership & - & firm-level \\
Number of employees & - & firm-level \\
Credit*external finance & - & sector-level \\
Recovery*turnover & & sector-level \\
\hline
\end{tabular}

